\title{
Pengaruh Konsentrasi Enzim $\alpha$ - Amilase pada Hidrolisis Pati Labu Jepang (Kabocha)
}

\author{
The Effect of Enzyme $\alpha$ - Amylase Concentration to Hydrolysis of Japanese Pumpkin (Kabocha)
} Starch

\author{
Sri Wahyuningsih \\ Universitas PGRI Madiun, Teknik Kimia \\ email: swahyu@unipma.ac.id
}

Received: 10/06/19; Revised: 27/06/19; Accepted: 27/06/19

\begin{abstract}
Abstrak
Labu Jepang (Kabocha) merupakan tanaman yang berpotensi untuk dijadikan gula glukosa karena memiliki kandungan karbohidrat yang cukup tinggi yakni senilai 13\%. Penelitian ini bertujuan untuk mengetahui pengaruh konsentrasi enzim $\alpha$-amilase pada hidrolisis enzimatis labu jepang (Kabocha). Penelitian ini dilakukan melalui 4 tahap yakni pelarutan, likuifikasi, sakarifikasi, dan pemucatan. Pada tahap likuifikasi pati diubah menjadi dekstrin oleh enzim $\alpha$-amilase dengan kombinasi perlakuan faktorial 3 x 3 yang terdiri dari 3 kali pengulangan pada satu perlakuan variasi konsentrasi enzim $0,01 \%, 0,02 \%$ dan $0,03 \%$ berat kering bahan. Analisa kuantitatif gula reduksi diperoleh dengan metode spektrofotometer UV-Vis menggunakan pereaksi Iodium pada panjang gelombang ( $\lambda$ ) 348 $\mathrm{nm}$. Hasil yang diperoleh menunjukkan bahwa hidrolisis pati menghasilkan kadar gula reduksi terbaik dengan penggunaan enzim $0,03 \%$ berat kering bahan dengan waktu hidrolisis selama 120 menit.
\end{abstract}

Kata Kunci: amilase, enzim, hidrolisis, labu jepang.

\begin{abstract}
Japanese pumkin (Kabocha) is a potential plant which can modified as alternative sugar because it has $13 \%$ carbohydrate. The aim of this research is determained the concentration effect of $\alpha$-amylase on Japanese pumpkin starch hydrolysis. This research was carried out on 4 stages namely dissolving, liquification, saccharification, and bleaching. This research is focused on liquification stage, which starch was converted to dextrin by $\alpha$-amylase enzyme with factorial combination $3 \times 3$ treatment that consist of 3 repetation in one treatment variation of enzyme concentration $0.01 \%, 0.02 \%$ and $0.03 \%$ weight of dry material. Quantitative analysis of reducing sugars was obtained by UV-Vis spectrophotometer with Iodine reagent at wavelength ( $\lambda$ ) $348 \mathrm{~nm}$. Results showed that the best starch hydrolized as reducing sugar with $0.03 \%$ of enzyme in 120 minutes hydrolisis.
\end{abstract}

Keywords: amylase, enzyme, hydrolisis, Japanese pumpkin

\section{PENDAHULUAN}

Gula merupakan komponen vital dalam kehidupan karena merupakan sumber kalori terbesar yang diperlukan oleh tubuh dan memiliki sifat mudah dicerna. EFSA (The European Food Safety Authority) merekomendasikan kandungan karbohidrat sebesar 45-60\% dari keseluruhan energy intake. Sirup glukosa merupakan gula berfase cair yang diperoleh dari hasil hidrolisis pati baik secara asam maupun secara enzimatis (Alifia \& Aji, 2015). Glukosa mampu memberikan performa (volume, rasa, 
tekstur, kilau, efek mengembang, serta efek mengawetkan) yang lebih baik pada produk yang ditambahkan daripada pemakaian sukrosa.

Kebutuhan akan gula yang sehat dalam hal ini glukosa selalu mengalami kenaikan yang signifikan dari tahun ke tahun, terutama untuk memenuhi kebutuhan konsumsi secara langsung (industri makanan), produk farmasi, serta pemenuhan kebutuhan gula fermentasi untuk produk yang lain melalui biokonversi. Di dunia farmasi, konsumsi glukosa terbesar untuk memenuhi kebutuhan infus rumah sakit yang dimanfaatkan sebagai sumber energi utama bagi tubuh pasien. Sedangkan untuk industri makanan, glukosa lebih digemari karena memiliki banyak kelebihan jika dibandingkan sukrosa. Kenyataan ini memicu munculnya berbagai upaya untuk menghasilkan sirup glukosa sebagai bahan pemanis alternatif pengganti sukrosa.

Labu jepang (Kabocha) tergolong tanaman semusim yang tumbuh menjalar atau merambat dan berbatang kokoh. Batang utama berbuku-buku dan berambut kasar. Buah (Kabocha) termasuk buah sejati tunggal dan berbiji banyak. Bijinya terdapat di dalam daging buah. Tanaman ini tumbuh baik pada ketinggian 1000 meter di atas permukaan laut dengan curah hujan sedang. Tanaman ini merupakan tanaman yang toleran terhadap kekeringan, relatif sedikit membutuhkan air dan sensitif terhadap genangan air. (Kabocha) dapat ditanam di seluruh daerah di Indonesia dan lebih baik ditanam pada musim kemarau (Imdad \& Nawangsih,1995).

Tanaman yang kaya dengan kandungan karotenoid ini berpeluang sebagai bahan dasar pembuatan sirup glukosa karena kandungan karbohidrat yang tinggi mencapai 13\% (Lomboan, 2002). Selain karena kandungan gizi yang baik, labu jepang diharapkan mampu mengurangi ketergantungan manusia terhadap sukrosa dari tebu dan menjadi alternatif pilihan gula/sirup glukosa.

Penelitian mengenai pembuatan sirup glukosa diantaranya adalah dari ubi jalar dengan metode enzimatis yang melakukan optimasi pada proses likuifikasi dan sakarifikasi (Robi'a \& Aji, 2015). Penelitian pembuatan sirup glukosa dengan variasi konsentrasi substrat (labu jepang) melalui hidrolisis enzimatis menggunakan enzim $\alpha$-amilase belum pernah dilakukan sebelumnya, sehingga perlu dilakukan penelitian agar didapat hasil yang dapat menambah khazanah mengenai pembuatan sirup glukosa sebelumnya.

Proses hidrolisis pati merupakan pemecahan molekul amilum menjadi komponen penyusunnya yang lebih sederhana seperti dekstrin, maltotriosa, maltose dan glukosa. Proses hidrolisis secara enzimatis lebih efektif bila dibandingkan hidrolisis asam karena enzim memutus ikatan glikosidik secara spesifik, tanpa menyisakan residu dan minimum kerusakan warna (Azmi dkk., 2017). Proses ini terjadi melalui 3 tahap yaitu gelatinisasi, likuifikasi dan sakarifikasi. Gelatinasi merupakan tahap inisiasi sebelum terjadinya likuifikasi dengan pembengkakan granula pati akibat pemanasan yang memutus ikatan hidrogen antar molekul pada ikatan glikosidik pati. Proses gelatinasi ini memegang peranan penting karena menjadi penentu laju proses likuifikasi. Likuifikasi merupakan proses inti hidrolisis enzimatis yang dikendalikan oleh enzim $\alpha$-amilase dimana pati dihidrolisis menjadi molekul-molekul yang lebih sederhana seperti oligoskarida, 
maltosa dan dekstrin. Enzim $\alpha$-amilase memegang peran penting untuk menentukan cepat lambatnya proses likuifikasi, dengan cara memecah ikatan $\alpha$ $(1,4)$ glikosidik secara spesifik pada bagian dalam substrat dan menghasilkan gula reduksi serta dekstrin dalam jumlah besar yakni encapai 95\% (Hua \& Yang, 2016). Kinetika reaksi pati oleh enzim $\alpha$ amilase dapat digambarkan sebagai persamaan kesetimbangan berikut :

enzim + pati $\underset{\mathrm{b}}{\stackrel{\mathrm{a}}{\rightleftharpoons}}$ Enzim-pati $\stackrel{\mathrm{c}}{\longrightarrow}$ enzim + produk

Dari persamaan tersebut terlihat bahwa enzim $\alpha$-amilase-pati membentuk suatu kompleks dalam reaksi kesetimbangan yang mengalami reaksi berkelanjutan menjadi produk enzim murni dan oligosakarida yang sifatnya irreversible (Madsen, 1974). Setelah sisi aktif enzim telah terisi seluruhnya, kecepatan reaksi ditentukan oleh konsentrasi substrat dalam hal ini pati.

Tahap lanjut proses pembuatan sirup glukosa adalah proses sakarifikasi yang melibatkan enzim amiloglukosidase yang berperan memecah pati menjadi hasil akhir gula reduksi. Enzim yang aktif pada $\mathrm{pH}$ 4,5-5,0 ini bekerja dengan cara menghidrolisis ikatan 1,4 glikosida maupun 1,6 glikosida dari pati dan oligosakarida menjadi unit-unit glukosa,

\section{METODE PENELITIAN}

\section{Alat dan Bahan}

Alat-alat yang digunakan adalah alat-alat standar laboratorium antara lain tabung reaksi, gelas baker, erlenmeyer, pipet ukur, flow pipet, pipet tetes, $\mathrm{pH}$ meter, cawan alumunium, cawan porselen, alumunium foil, dan kertas payung, magnetic stirrer, viskosimeter, spektrofotometer, hidrometer, waterbath shaker, vortex, oven, desikator, vaccum rotary evaporator.

Bahan dasar pada penelitian ini adalah buah labu jepang (Kabocha) dari desa Plaosan Magetan, JawaTimur. Bahan yang digunakan untuk menghidrolisis pati adalah enzim $\alpha$-amilase merek Liquozyme Supra produksi dari Liquid Sunshine Destilery.

\section{Metodologi}

Proses pembuatan sirup glukosa pada penelitian ini dilakukan melalui serangkaian perlakuan hingga dihasilkan bubur labu jepang (Kabocha) siap olah.

a. Pelarutan pati

Berat kering pasta pati yang digunakan adalah 40 gram untuk membuat konsentrasi larutan pati sebesar $40 \%$ dalam $100 \mathrm{ml}$ aquades.

b. Proses likuifikasi

Pada proses ini terjadi hidrolisis pati menjadi dekstrin oleh enzim $\alpha-$ amylase.

Tahap ini dilakukan dengan kombinasi perlakuan faktorial $3 \times 3$ yang terdiri dari 3 kali ulangan pada satu perlakuan variasi konsentrasi enzim $0,01 \%, 0,02 \%$ dan $0,03 \%$ berat kering bahan. Adapun rancangan perlakuan dapat diringkas pada Tabel. 1 .

Tabel 1. Rancangan Penelitian

\begin{tabular}{|c|c|c|c|c|}
\hline \multirow{2}{*}{$\begin{array}{l}\text { Waktu } \\
\text { Hidrolisis }\end{array}$} & \multirow[t]{2}{*}{ Ulangan } & \multicolumn{3}{|c|}{$\begin{array}{c}\text { Konsentrasi Enzim (\% } \\
\text { berat kering bahan) }\end{array}$} \\
\hline & & $\mathbf{0 , 0 1}$ & $\mathbf{0 , 0 2}$ & $\mathbf{0 , 0 3}$ \\
\hline \multirow{3}{*}{90 menit } & 1 & $\mathrm{~A} 1^{\mathrm{a}}$ & $\mathrm{B} 1^{\mathrm{a}}$ & $\mathrm{C} 1^{\mathrm{a}}$ \\
\hline & 2 & $\mathrm{~A} 1^{\mathrm{b}}$ & $\mathrm{B} 1^{\mathrm{b}}$ & $\mathrm{C} 1^{\mathrm{b}}$ \\
\hline & 3 & $\mathrm{~A} 1^{\mathrm{c}}$ & $\mathrm{B} 1^{\mathrm{c}}$ & $\mathrm{C} 1^{\mathrm{c}}$ \\
\hline \multirow{3}{*}{120 menit } & 1 & $\mathrm{~A} 2^{\mathrm{a}}$ & $\mathrm{B} 2^{\mathrm{a}}$ & $\mathrm{C} 2^{\mathrm{a}}$ \\
\hline & 2 & $\mathrm{~A} 2^{\mathrm{b}}$ & $\mathrm{B} 2^{\mathrm{b}}$ & $\mathrm{C} 2^{\mathrm{b}}$ \\
\hline & 3 & $\mathrm{~A} 2^{\mathrm{c}}$ & $\mathrm{B} 2^{\mathrm{c}}$ & $\mathrm{C} 2^{\mathrm{c}}$ \\
\hline \multirow{3}{*}{150 menit } & 1 & $\mathrm{~A} 3^{\mathrm{a}}$ & $\mathrm{B} 3^{\mathrm{a}}$ & $C 3^{\mathrm{a}}$ \\
\hline & 2 & $\mathrm{~A} 3^{\mathrm{b}}$ & $\mathrm{B} 3^{\mathrm{b}}$ & $\mathrm{C} 3^{\mathrm{b}}$ \\
\hline & 3 & $\mathrm{~A} 3^{\mathrm{c}}$ & $\mathrm{B} 3^{\mathrm{c}}$ & $\mathrm{C} 3^{\mathrm{c}}$ \\
\hline
\end{tabular}


c. Proses sakarifikasi

Sakarifikasi merupakan proses perubahan dekstrin menjadi gula yang melibatkan enzim amiloglukosidase. Pati yang telah menjadi dekstrin didinginkan hingga $60 \quad{ }^{\circ} \mathrm{C}$ dan ditambahkan enzim amiloglukosidase Proses ini berlangsung sekitar 72 jam dengan pengadukan terus menerus.

d. Proses pemucatan

Pemucatan bertujuan untuk menghilangkan bau, warna dan kotoran, serta menghentikan aktifitas enzim. Adsorben yang digunakan adalah karbon aktif sebanyak $0.5 \%$ $1 \%$ dari bobot pati.

e. Penyaringan

Penyaringan bertujuan untuk memisahkan karbon aktif dari larutan sirup yang sebelumnya digunakan untuk menyerap kotoran dalam sirup

f. Penguapan

Tahap terakhir adalah penguapan untuk memperoleh sirup dengan kekentalan yang dikehendaki.

\section{Analisa Kualitatif}

Uji kualitatif gula pereduksi menggunakan metode uji Benedict sebanyak $5 \mathrm{~mL}$ pereaksi Benedict ditambahkan pada $5 \mathrm{~mL}$ sampel dan disimpan dalam penangas air selama 3 menit, selanjutnya didinginkan dan diamati perubahan warnanya.

\section{Analisa Kuantitatif}

Metode yang digunakan adalah metode asam fenol sulfat. Pembuatan kurva standar dilakukan terlebih dahulu dengan membuat larutan standar gula dengan konsentrasi yaitu 0, 25, 50, 75, 100, 125, 150, dan 200 ppm. Sampel gula diambil dengan pipet sebanyak 0,5 $\mathrm{mL}$ dan dimasukkan ke dalam tabung reaksi dan ditambahkan $0,5 \mathrm{~mL}$ fenol $5 \%$ dan dikocok. Kemudian, pada sampel ditambahkan 2,5 $\mathrm{mL} \mathrm{H}_{2} \mathrm{SO}_{4}$ pekat secara hati-hati melalui dinding tabung dan didiamkan selama 10 menit dalam air. Selanjutnya dikocok dan didiamkan kembali selama 20 menit. Setelah dingin, diukur nilai absorbansinya menggunakan spektrofotometer pada $\lambda$ 480- $490 \mathrm{~nm}$. Nilai absorbansi yang diperoleh kemudian dimasukkan perhitungan hasil kurva standar. Larutan blanko yang digunakan adalah akuades yang diberi perlakuan sama seperti sampel.

\section{HASIL DAN PEMBAHASAN}

Analisis Gula Reduksi Secara Kualitatif

Prosedur pengujian gula reduksi secara kualitatif dilakukan melalui Uji Benedict. Prinsip dari uji Benedict ini adalah reduksi ion $\mathrm{Cu}^{2+}$ dari $\mathrm{CuSO}_{4} .5 \mathrm{H}_{2} \mathrm{O}$ pada suasana alkalis (yang diperoleh dari $\mathrm{Na}_{2} \mathrm{CO}_{3}$ dan $\mathrm{Na}$ sitrat pada reagen Benedict) menjadi ion $\mathrm{Cu}^{+}$(mengendap menjadi $\mathrm{Cu}_{2} \mathrm{O}$ ) oleh gugus aldehid atau keton bebas pada gula reduksi yang terdapat di dalam sampel (Azmi $d k k$., 2017). Hasil pengujian gula reduksi secara kualitatif terhadap sirup glukosa dengan menggunakan Uji Benedict terlihat pada Tabel 2.

Tabel 2. Hasil Pengujian Gula Reduksi secara Kualitatif

\begin{tabular}{cccc}
\hline $\begin{array}{c}\text { Waktu } \\
\text { (menit) }\end{array}$ & \multicolumn{3}{c}{ Konsentrasi enzim $\boldsymbol{\alpha}-$} \\
amilase $(\%)$ \\
$\mathbf{0 , 0 1}$ & $\mathbf{0 , 0 2}$ & $\mathbf{0 , 0 3}$ \\
\hline $\mathbf{9 0}$ & + & + & + \\
$\mathbf{1 5 0}$ & + & + & + \\
\hline
\end{tabular}

Keterangan :

$+\quad$ : ada endapan merah bata

- $\quad$ : tidak ada endapan merah bata 


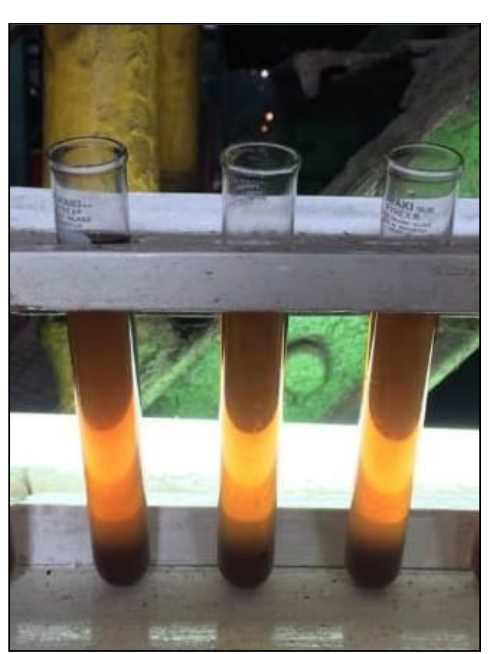

Gambar 1. Hasil Uji Benedict Hidrolisa Pati Labu Jepang (kabocha)

Seperti pada Gambar 1, hasil pengujian gula reduksi menunjukkan hasil positif yang ditunjukkan adanya endapan merah bata meskipun intensitasnya berbeda satu sama lain. Hal ini menunjukkan bahwa terjadi proses hidrolisis pada sampel labu jepang yang mengandung pati. Reaksi yang terjadi adalah:

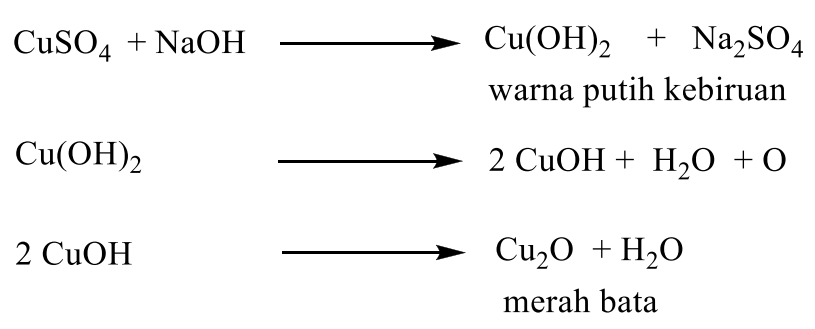

\section{Analisis Gula Reduksi Secara Kuantitatif}

Analisa kuantitatif gula reduksi diperoleh dengan metode fenol sulfat yang diukur dengan menggunakan spektrofotometer UV-Vis kemudian absorbansi sampel diukur pada panjang gelombang $(\lambda)$ 480-490 nm. Data absorbansi analisa gula reduksi secara kuantitatif dikonversi menjadi data konsentrasi menggunakan hukum Lambert Beer disajikan pada Tabel 3.
Tabel 3. Hasil Pengukuran Kuantitatif Gula Reduksi

\begin{tabular}{ccccc}
\hline \multirow{2}{*}{$\begin{array}{l}\text { Waktu } \\
\text { Hidrolisis } \\
\text { (menit) }\end{array}$} & \multicolumn{2}{c}{$\begin{array}{c}\text { Kadar Gula Reduksi } \\
(\mathbf{\%})\end{array}$} & $\begin{array}{c}\text { Rata- } \\
\text { rata }\end{array}$ \\
\cline { 2 - 4 } & $\mathbf{0 , 0 1}$ & $\mathbf{0 , 0 2}$ & $\mathbf{0 , 0 3}$ & \\
\hline $\mathbf{9 0}$ & $6,85^{\mathrm{a}}$ & $7,95^{\mathrm{a}}$ & $17,85^{\mathrm{a}}$ & $9,88^{\mathrm{x}}$ \\
\hline $\mathbf{1 2 0}$ & $10,25^{\mathrm{a}}$ & $18,85^{\mathrm{a}}$ & $21,96^{\mathrm{a}}$ & $17,02^{\mathrm{y}}$ \\
\hline $\mathbf{1 5 0}$ & $9,65^{\mathrm{a}}$ & $10,25^{\mathrm{a}}$ & $12,35^{\mathrm{a}}$ & $13,48^{\mathrm{x}}$ \\
\hline Rata-rata & $8,98^{\mathrm{x}}$ & $12,35^{\mathrm{x}}$ & $17,39^{\mathrm{y}}$ & \\
\cline { 1 - 3 } &
\end{tabular}

Keterangan: angka yang diikuti huruf yang sama pada kolom dan baris yang sama menunjukkan tidak ada perbedaan signifikan pada tingkat kepercayaan $95 \%$

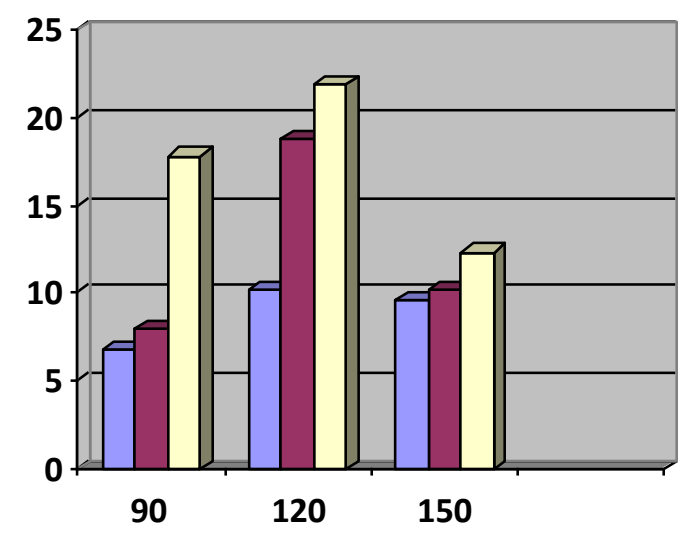

Gambar 2. Grafik Hasil Analisa Kuantitatif Gula Reduksi Sirup Glukosa Labu jepang

Hasil pengukuran uji kandungan gula reduksi sirup glukosa labu jepang (Kabocha) menunjukkan adanya kesesuaian dengan kurva standar glukosa. Hal ini menunjukkan bahwa pati labu jepang telah mengalami hidrolisis enzimatis menjadi glukosa.

Grafik pada Gambar 2 menunjukkan bahwa nilai konsentrasi glukosa terbesar diperoleh pada penggunaan konsentrasi enzim terbesar yakni $0,03 \%$ berat kering bahan yang menunjukkan bahwa makin tinggi konsentrasi enzim yang dipergunakan maka makin banyak ikatan glikosidik yang terhidrolisis menjadi produk glukosa. Hal ini sesuai dengan penelitian-penelitian 
sebelumnya yang menyatakan bahwa jumlah pati makin menurun seiring dengan penambahan dosis enzim (Smith, 1970).

Enzim merupakan katalis biologi yang membantu akselerasi reaksi kimia, dan memiliki peranan sebagai penentu laju reaksi. Konsentrasi atau dosis enzim adalah jumlah enzim per total pelarut, bila konsentrasi enzim terlalu rendah maka reaksi akan berlangsung lebih lambat dan menghasilkan produk dalam jumlah yang rendah (Wee $d k k$., 2011). Hal ini seperti ditunjukkan pada hasil hidrolisis pati labu jepang dengan menggunakan dosis enzim $0,01 \%$ per berat kering bahan pada Gambar 2, yakni pada konsentrasi tersebut jumlah produk gula reduksi paling rendah bila dibandingkan dengan dosis enzim yang lebih tinggi.

Namun demikian bila konsentrasi enzim dinaikkan terus menerus produk glukosa tidak meningkat secara signifikan (Wee $d k k ., 2011$ ), kondisi ini sebaiknya dihindari selama proses produksi mengingat harga enzim komersial yang mahal. Pernyataan ini diperkuat dengan data pada penggunaan dosis enzim $0,03 \%$ yang mengalami peningkatan bila dibandingkan dengan pemakaian dosis enzim $0,02 \%$ seperti disajikan pada Gambar 2 di atas.

Beberapa penelitian sebelumnya menyatakan bahwa penggunaan beberapa enzim secara bersamaan yakni enzim $\alpha$ amilase untuk likuifikasi dan glukoamilase untuk sakarifikasi, pada rentang waktu tertentu dapat mengalami reaksi kondensasi glukosa yang berkebalikan (reverse reaction) yang dikatalisis oleh enzim glukoamilase (Findrik $d k k$., 2010). Hal ini sesuai dengan hasil data penelitian pada Gambar 2 yang menunjukkan pada waktu hidrolisis 150 menit lebih rendah bila dibandingkan 120 menit, dengan kata lain makin lama rentang waktu hidrolisis maka hasilnya tidak linear meningkat tetapi menurun.

\section{KESIMPULAN}

Labu Jepang (Kabocha) memiliki potensi untuk dijadikan sirup glukosa karena mengandung pati yang dapat dihidrolisis secara enzimatis. Konsentrasi/dosis enzim $0,03 \%$ berat kering bahan memberikan hasil optimum dengan waktu hidrolisis 120 menit.

\section{DAFTAR RUJUKAN}

Alifia, Y.R., \& Aji, S., (2015). Hidrolisis Tepung Ubi Jalar Ungu (Ipomea Batatas l.) secara Enzimatis Menjadi Sirup Glukosa Fungsional: Kajian Pustaka, Jurnal Pangan dan Agroindustri, 3(3), 1152-1159

Azmi, A. S., Malek, M. I. A., \& Puad N. I. M. (2017). A Review on Acid and Enzymatic Hydrolyses of Sago Starch, International Islamic University Malaysia, International Food Research Journal, 24, 265273

Findrik, Z., Presečki, A. V. \& VasićRački, D. (2010). Mathematical modeling of maltose hydrolysis in different types of reactor, Bioprocess and Biosystems Engineering, 33(3), 299-307

Hua, X. \& Yang, R. (2016). Enzymes in starch processing. In Chandrasekaran, M. (Ed.) Enzymes in Food and Beverage Processing, p. 139-170. Boca Raton: CRC Press.

Imdad, H. P., \& Nawangsih, A. A. (1995). Sayuran Jepang. Jakarta: Penebar Swadaya 
Lomboan, N. J. (2002). Macam Macam Jenis Labu. Jakarta: Nirmala edisi tahunan.

Madsen, G. (1974). The Application of Bacterial Amylase in The Cane Sugar Industry. Proc Philippines Sug Technol, 22, 227-235.

Smith, I. A. (1970). Factors affecting enzymatic starch hydrolysis in sugar solutions. Proceedings of The South African Sugar Technologists' Association, 44, 88-93.

Robi'a. \& Aji S., (2015). Karakteristik Sirup Glukosa dari Tepung Ubi Ungu (Kajian Suhu Likuifikasi dan Konsentrasi $\alpha$-Amilase): Kajian Pustaka. Jurnal Pangan dan Agroindustri, 3(4), 1531-1537

Wee, L. L., Annuar, M., Ibrahim, S. \& Chisti, Y. (2011). Enzymemediated production of sugars from sago starch: statistical process optimization, Chemical Engineering Communications, 198(11), 1339-1353 